\title{
Assessment of a medetomidine/propofol total intravenous anaesthesia (TIVA) for clinical anaesthesia in equidae
}

\author{
Regula Bettschart-Wolfensberger, Sarah Freeman, R. W. Bettschart, A. Fürst and Kathleen W. Clarke
}

Veterinär-Chirurgische Klinik der Universität Zürich, Schweiz

\section{Summary}

This study investigated the clinical use of a medetomidine/propofol TIVA technique in horses. Twenty seven equidae of mixed breed, age [mean (SD (range)] $2.9 \pm 2.74(0.11-11)$ years, weight $237 \pm 130.22$ (64-470) kg (in 12 horses, anaesthetised in the field weight was not scaled but judged by the first authour) were anaesthetised. The following surgeries were performed: intraabdominal (3), castration (15), joint flush (4), screw removal (1), desmotomy (3), dermatoma removal (1).

In the field 6 wild horses were premedicated with $0.03 \mathrm{mg} / \mathrm{kg}$ acepromazine IM. All the horses were sedated with $7 \mathrm{mcg} / \mathrm{kg}$ medetomidine $\mathrm{IV}$, anaesthesia was induced 10 minutes later with $2 \mathrm{mg} / \mathrm{kg}$ propofol IV. If the patient lifted its head when beeing approached for propofol administration, sedation was deepened with incremental boli of medetomidine. After anaesthesia induction trachea was intubated and oxygen administered at FIO2 $>90 \%$ in 15 horses. Anaesthesia was maintained with $3.5 \mathrm{mcg} / \mathrm{kg} / \mathrm{h}$ medetomidine IV and propofol infused to effect (initial dose $0.1 \mathrm{mg} / \mathrm{kg} / \mathrm{min}$ ). Heart rate, respiratory rate, propofol dose and arterial blood pressure were recorded every five minutes and arterial blood gases every 15 minutes. Quality of sedation, anaesthetic induction and recovery were graded. Arterial bloodpressures and arterial blood gases were analysed in a preliminary manner by descriptive statistical methods. Heart rates and respiratory rates were analysed using ANOVA for repeated measures. To detect differences to preanaesthetic values Dunnett's post test was performed. Eleven horses required additional $2 \mathrm{mcg} / \mathrm{kg}$ and one horse $6 \mathrm{mcg} / \mathrm{kg}$ medetomidine for adequate sedation prior to induction. Induction of anaesthesia was variable: excellent in 3, good in 18, fair in 4 and poor (unsatisfactory) in 2 horses. In a 28 th horse anaesthesia induction was very poor and transfer from induction area to theatre was not possible even after application of several boluses of propofol (total dose $2 \mathrm{mg} / \mathrm{kg}$ ) and thiopentone (total dose $2.5 \mathrm{mg} / \mathrm{kg}$ ) as whenever lifted paddeling of the limbs occurred. The use of propofol as an induction agent was stopped after this incidence. After sedation three horses showed second degree AV blocks two of which were treated with atropine. Compared to presedation values respiratory rate as well as heart rate were significantly reduced throughout anaesthesia. During anaesthesia, range of mean values (absolute range) were, for respiratory rate 12.4-17.7 (4-32) breaths/ $\mathrm{min}$, heart rate 36.3-46.8 (15-58) bpm, mean arterial blood pressure 95.6-111 (84-128) mmHg, propofol infusion 0.063-0.18mg/ $\mathrm{kg} / \mathrm{min}, \mathrm{p}_{\mathrm{a}} \mathrm{O}_{2} 23.2-31.8(11.7-59.7) \mathrm{kPa}, \mathrm{p}_{\mathrm{a}} \mathrm{CO}_{2} 6.1-7$ (5.2-8.5) kPa. Anaesthetic quality was excellent: spontaneous movement occurred in 6 horses, but was slow and easily controlled with increments of propofol $(0.05-0.1 \mathrm{mg} / \mathrm{kg})$. Anaesthetic duration was 57.9 (38.16 (15-175) min. Recovery was completed unaided within 24.3 (10.66 (10-44.8) min. It was uneventful in all horses. Medetomidinepropofol TIVA at dose rates administered in the current study produced good quality anaesthesia with cardiopulmonary depression within ranges commonly recorded during inhalation anaesthesia in horses. However anaesthetic induction was variable, and appeared to be inferior to that achieved with induction regimes including ketamine.

Keywords: $\quad$ anaesthesia, horse, medetomidine, propofol, total intravenous anaesthesia

\section{Anwendung von Medetomidin-Propofol Total Intravenöser Anästhesie (TIVA) in der Pferdepraxis}

In der vorliegenden Studie wurde bei 16 Pferden in einer Klinik und bei 12 Pferden unter Feldbedingungen die Anwendung von Medetomidin und Propofol zur Allgemeinanästhesie getestet. Sie waren 0,1 1-1 1 Jahre alt (2,9 $\pm 2,74$; Mittelwert \pm Standardabweichung), wogen 64-470 $(237 \pm 130,22) \mathrm{kg}$ und waren von unterschiedlicher Rasse. Folgende Operationen wurden durchgeführt: Entfernung von Knochenimplantaten (1), Desmotomie (3), Gelenkspülung (4), Kastration (15), Dermatom Entfernung (1), Kastration intraabdominaler Hoden (3).

Unter Feldbedingungen wurden die Pferde mit 0,03 mg/kg Acepromazin i.m. prämediziert. Alle Pferde erhielten $7 \mu \mathrm{g} / \mathrm{kg} \mathrm{Medetomidin} \mathrm{i.v.} \mathrm{zur}$ Sedation. Nach 10 Minuten wurde die Anästhesie mit 2 mg/kg Propofol i.v. eingeleitet. Die Pferde atmeten spontan, in der Klinik wurden sie intubiert und atmeten $>90 \% \mathrm{O}_{2}$. Die Anästhesie wurde aufrecht erhalten durch eine konstante Infusion von Medetomidin (3,5 $\left.\mu \mathrm{g} / \mathrm{kg} / \mathrm{h}\right) \mathrm{und}$ Propofol infundiert nach Wirkung (initiale Dosis $0,1 \mathrm{mg} / \mathrm{kg} / \mathrm{min}$ ). Arterielle Blutdruck- und arterielle Blutgaswerte wurden durch deskriptive Statistik ausgewertet. Herz- und Atemfrequenzen wurden mittels Varianzanalyse für wiederholte Messungen untersucht und Unterschiede zu präanästhetischen Werten mittels Dunnet's T-test ermittelt.

Die Qualität der Einleitung war sehr gut bei 3, gut bei 18, zufriedenstellend bei 4 und nicht zufriedenstellend bei 2 Pferden. Beim 28 sten Pferd war die Einleitungsphase so unruhig, dass es trotz Propofol- $(2 \mathrm{mg} / \mathrm{kg})$ sowie Thiopenthalapplikation $(2,5 \mathrm{mg} / \mathrm{kg}) \mathrm{nicht} \mathrm{aufhörte} \mathrm{zu}$ bewegen und deshalb nicht in den Operationsraum transportiert werden konnte. Es kam während der Anästhesie zu einem signifikanten Abfall der Atem- sowie der Herzfrequenz. Die Bereiche der Mittelwerte (Minima-Maxima) der überwachten Parameter während der Anästhesie betrugen: Atemfrequenz: 12,4-17,7 (4-32) Atemzüge/min, Herzfrequenz: 36,3-46,8 (15-58) Schläge/min, mittlerer arterieller Blutdruck 95,6-1 11 (84-128) mmHg, $\mathrm{p}_{\mathrm{a}} \mathrm{O}_{2}: 32,2-31,8(11,7-59,7) \mathrm{kPa}, \mathrm{P}_{\mathrm{a}} \mathrm{CO}_{2}: 6,1-7(5,2-8,5) \mathrm{kPa}$. Die Propofolinfusionsrate betrug 0,063-0,18 mg/kg/min. Die Anästhesiequalität war exzellent und alle Eingriffe konnten erfolgreich durchgeführt werden. Nach einer Anästhesiedauer von 15-175 Minuten (im Mittel 57,9) standen die Pferde innerhalb von 10-44,8 Minuten (im Mittel 24,3) ruhig auf. Die Qualität der Einleitung war sehr unterschiedlich und teilweise von unakzeptabler Qualität. Deshalb empfehlen die Autoren zur Anästhesieeinleitung von Pferden Ketamin dem Propofol vorzuziehen. Hingegen bewirkte Propofol in Kombination mit Medetomidin zur Aufrechterhaltung einer Allgemeinanästhesie geringe Nebenwirkungen auf Herz, Kreislauf und Atmung. Außerdem verliefen die Aufwachphasen ruhig und waren von kurzer Dauer.

Schlüsselwörter: Anästhesie, Pferd, Medetomidin, Propofol, total intravenöse Anästhesie 


\section{Introduction}

Anaesthesia related fatality rate is higher in horses than in any other domestic species (Johnston et al., 1995). One of the few facts known about this phenomenon is that the length of anaesthesia significantly influences the outcome (Johnston et al., 1995). An increase in risk with anaesthesia duration was noted, probably related to the cardiopulmonary depressant effects of halothane and the fact that horses are more prone to develop problems due to cardiopulmonary depression than small animals or humans. Total intravenous anaesthesia (TIVA) is less cardiopulmonary depressant than clinically used inhalational anaesthetic regimes (Luna et al., 1996). Thus it would seem to be wise to anaesthetise horses for long anaesthesias using TIVA combinations. However, most TIVA in horses include ketamine, but with infusions of 2 hours or longer, ketamine's major metabolite norketamine accumulates (Taylor and Luna, 1995; Nolan et al., 1996). Due to its hallucinatory properties (Chang and Glazko, 1974), norketamine may lead to signs of apparent ketamine overdose during the horses recovery (Wolfensberger, 1993; Taylor and Luna, 1995; Bettschart-Wolfensberger et al., 1996; Nolan et al., 1996). Therefore TIVA involving ketamine is not ideal for longer anaesthesias.

To create a TIVA regime suitable for long anaesthesias in horses, a combination of medetomidine and propofol, has been elaborated (Bettschart-Wolfensberger et al., 2001a). Compared to other work that explored the use of propofol in this species in combination with other sedatives (Nolan and Hall, 1985; Taylor, 1989a; Hartsfield et al., 1994; Matthews et al., 1994; 1997; Mama et al., 1998; Taylor et al., 1997), medetomidine induced major dose reductions of propofol. The resulting cardiovascular depression was remarkably low (BettschartWolfensberger et al., 2001b) and was comparable to other TIVA regimes including ketamine (Greene et al., 1986; Young et al., 1993; Bettschart-Wolfensberger et al., 1996, Luna et al., 1996), but less than with clinically used inhalational anaesthetic regimes (Luna et al., 1996).

Medetomidine-propofol TIVA has been tested in experimental animals in anaesthesias as long as 4 hours (Bettschart-Wolfensberger et al., 2001a+b). Anaesthesia was easy to maintain and control. Even after the long duration of 4 hours of anaesthesia, recoveries were quick and of good quality. Under clinical conditions other factors than length of anaesthesia influence the outcome as for example type of surgery (Young and Taylor, 1993), nature (Whitehair et al., 1993), clinical condition and body weight of the horse (Johnston et al., 1995a). Thus a defi- nitive testing of any new drug combination is only possible under clinical circumstances.

The present study wanted to test clinically medetomidine-propofol anaesthesia during all types of surgeries in horses of different breed, weight, character and age.

\section{Materials and methods}

Animals

The previously elaborated TIVA regime with medetomidine and propofol was tested in a total of 27 equidae. In a 28th horse anaesthesia was only induced, but then the horse was allowed to recover without surgery because of occurring problems. 15 of the animals that underwent surgery were surgical patients and were anaesthetised inside a hospital henceforth termed "under clinical conditions". Another 12 animals were anaesthetised under field conditions. These were all stallions that had been raised in the field and had not been handled at all before the day of the surgery. Details of the animals and the surgeries performed are listed in table 1.

\section{Protocol}

The patients, that were anaesthetised under clinical conditions, were starved for 8-12 hours, if circumstances allowed this. A clinical examination was performed and if any abnormalities were detected, blood testing was done. Resting heart and respiratory rates were noted. Before the anaesthesia a catheter (Secalonl, Ohmeda, Hatfield, U.K.) was placed in the jugular vein and 8 horses were treated with penicillin (Peni G, Streuli AG, Switzerland) and gentamycin (Gentamycin Streuli, 10\% Streuli AG, Switzerland) i.v.. No analgesics were administered. The stallions that were castrated under field conditions were starved for 8-12 hours. To avoid injuries of people involved, 6 of the stallions were premedicated with $0.03 \mathrm{mg} / \mathrm{kg}$ acepromazine (ACP ${ }^{\circledR}, C$-Vet, Leyland, U.K.) i.m. and left unattended for 30 minutes. A clinical examination followed then, resting heart and respiratory rate were noted and a catheter (SecaIonl, Ohmeda, Hatfield, U.K.) was placed in the jugular vein. In both groups the animals were sedated by slow i.v. injection (over 2 minutes) of $7 \mu \mathrm{g} / \mathrm{kg}$ of medetomidine. Then they were given ten minutes to achieve maximal sedation. If sedation was considered unsatisfactory (i.e. the animal still reacting with a lift of the head or some steps backwards when being approached),

Tab. 1: Signalementof 27 equidae anaesthetised with medetomidine-propofol and type of surgery

Signalement und Art des chirurgischen Eingriffs von 27 Equiden anästhesiert mit Medetomidin-Propofol

\begin{tabular}{|l|l|l|}
\hline & Anaesthesias under clinical conditions & Anaesthesias under field conditions \\
\hline $\begin{array}{l}\text { aae, mean } \pm \text { SD } \\
\text { (range) }\end{array}$ & $3.5 \pm 3.29(0.1-11)$ years & $1.8 \pm 0.41(1-2)$ years \\
\hline $\begin{array}{l}\text { weiaht mean } \pm \text { SD } \\
\text { (range) }\end{array}$ & $240.0 \pm 1.07(64-470) \mathrm{kg}$ & $\begin{array}{l}231.6 \pm 135.12(120-450) \text { kg; the weight of these stallions was } \\
\text { not scaled but only judged by an experienced anaesthetist }\end{array}$ \\
\hline breed & $\begin{array}{l}6 \text { Warm Blood horses, 4 Thoroughbred, 1 donkey, } \\
2 \text { Shetland ponies, 2 ponies }\end{array}$ & 7 Warm Blood horses, 5 ponies \\
\hline type of surgery & $\begin{array}{l}\text { ioint flush (3), intraabdominal (3), screw removal } \\
(1), \text { desmotomy (1), wound revision (3), dermato- } \\
\text { ma removal (1), castration (3) }\end{array}$ & all castrations \\
\hline
\end{tabular}


another 2-5 $\mu \mathrm{g} / \mathrm{kg}$ of medetomidine were administered and anaesthesia induction delayed until satisfactory sedation was present. Just before induction heart and respiratory rate were noted again.

Anaesthesia was induced by i.v. injection of $2 \mathrm{mg} / \mathrm{kg}$ of propofol in all animals.

Under clinical conditions patients were intubated just after anaesthesia induction, and were allowed to breath $>90 \%$ oxygen spontaneously. Anaesthesia was maintained with an infusion of propofol started at an infusion rate of $0.1 \mathrm{mg} / \mathrm{kg} / \mathrm{min}$ and adjusted to the patients needs, using a syringe pump (P 4000, IVAC, Basingstoke, U. K.). Infusion rates of propofol were noted every 5 minutes. The clinical patients further got a continuous infusion of medetomidine at a dose rate of $3.5 \mu \mathrm{g} /$ $\mathrm{kg} / \mathrm{h}$ of medetomidine throughout the whole anaesthesia. Ringers lactate at a dose rate of $5 \mathrm{ml} / \mathrm{kg} / \mathrm{h}$ was infused to clinical patients as well. 10 minutes after the end of the propofol infusion clinical patients were given $2 \mu \mathrm{g} / \mathrm{kg}$ of medetomidine to calm recovery.

Under field conditions boli of propofol $(0.085-0.105 \mathrm{mg} / \mathrm{kg}$ ) were administered by hand injection every minute, according to the patients need and every five minutes the amount of propofol given was noted.

\section{Measurements}

After anaesthesia induction phases of apnoea were recorded and the position of the horses body during surgery was noted. Heart rate and respiratory rate were recorded every 5 minutes in all animals. In the field, heart rate was counted by palpating the pulse and respiratory rate by counting chest wall movements. Under clinical circumstance the patients were connected to an ECG (Kontron, Watford, U. K.) and intra-arterial blood pressure was measured continuously via a catheter in either the facial or the transverse facial artery. Arterial blood gas analysis was performed every 15 minutes.

Arterial blood pressures and arterial blood gases were analysed in a preliminary manner by descriptive statistical methods. Heart rates and respiratory rates were analysed using ANOVA for repeated measures. To detect differences to preanaesthetic values Dunnett's post test was performed.

If horses moved or any other side effects occurred, it was noted.

Surgeons were asked to judge relaxation and surgery conditions at the end of the procedure as good, adequate or unsatisfactory.

\section{Induction and recovery}

During induction one person stayed with the animal holding its head, to give a little support. We recorded during induction: Time from the end of propofol injection to recumbency and any striking events concerning induction. Quality of induction was graded based on a scale of 1 (worst) to 5 (best) represented in table 2.

For recovery the animals were left unattended in a smoothly padded recovery box (clinical cases) or in the field. Clinical patients were given $2 \mathrm{mg} / \mathrm{kg}$ of medetomidine 10 minutes after the end of the propofol infusion. When they started swallowing the endotracheal tube was removed, and the time noted. Quality of recovery was scored based on a scale of 1 (worst) to 5 (best) as described in table 2. Additionally during recovery the time of first movement, the time of first head lift, duration of sternal recumbency, time to gain standing position and the number of attempts to stand up were noted.

\section{Results}

Anaesthesia induction

A foal of 6 weeks, that was suffering from polyartheritis and a temperature of $39.6^{\circ} \mathrm{C}$ was given only $3 \mu \mathrm{g} / \mathrm{kg}$ of medetomidine, which induced sedation that seemed adequate for anaesthesia induction.

In all 12 of the stallions in the field an additional bolus of $2 \mu \mathrm{g} /$ $\mathrm{kg}$ and in one a bolus of $6 \mu \mathrm{g} / \mathrm{kg}$ of medetomidine was necessary, to achieve sedation that, subjectively assessed by the anaesthetist, seemed to be adequate for anaesthesia induction. Overall induction was excellent (5) in 3, good (4) in 18, fair (3) in 4, poor (2) in 2 and very poor (1) in one animal. One horse that showed a poor induction was a 2 year old stallion weighing $170 \mathrm{~kg}$ that had been very difficult to handle. It showed paddling of the limbs and spasms of the whole body up to one minute. The second one was a 6 year old cryptorchid thoroughbred stallion weighing $470 \mathrm{~kg}$ that was anaesthetised under clinical conditions. Both animals had seemed adequately sedated before anaesthesia induction.

The horse that showed a very poor induction was an 11 year old Warm Blood of $330 \mathrm{~kg}$, that required the removal of screws from the radius. It had shown deep sedation, but its heart rate had dropped from 48 before medetomidine administration to

Fig. 2: Induction and recovery scores.

Skala zur Beurteilung der Qualität von Anästhesieeinleitung und Aufwachphase

\begin{tabular}{|c|c|c|}
\hline & score & description \\
\hline \multirow{5}{*}{ induction } & 1 & $\begin{array}{l}\text { very poor, unpredictable fall of the } \\
\text { horse, the horse being injured }\end{array}$ \\
\hline & 2 & $\begin{array}{l}\text { poor, attaining recumbency } \\
\text { unpredictably, but no injuries }\end{array}$ \\
\hline & 3 & $\begin{array}{l}\text { fair, horse slowly attains sternal or } \\
\text { lateral recumbency, marked paddling } \\
\text { of limbs or shaking of head }\end{array}$ \\
\hline & 4 & $\begin{array}{l}\text { good, horse slowly attains } \\
\text { recumbency, only slight paddling of } \\
\text { limbs or shaking of the head }\end{array}$ \\
\hline & 5 & $\begin{array}{l}\text { excellent, recumbency achieved } \\
\text { slowly and smoothly, no paddling or } \\
\text { head shaking }\end{array}$ \\
\hline \multirow{5}{*}{ recovery } & 1 & $\begin{array}{l}\text { very poor, bad recovery with high } \\
\text { risc of injury }\end{array}$ \\
\hline & 2 & $\begin{array}{l}\text { poor, more than one attempt to } \\
\text { stand, horse excited }\end{array}$ \\
\hline & 3 & $\begin{array}{l}\text { good, but more than one attempt to } \\
\text { stand, horse stays calm }\end{array}$ \\
\hline & 4 & $\begin{array}{l}\text { good, } 1 \text { attempt to stand, some } \\
\text { ataxia }\end{array}$ \\
\hline & 5 & $\begin{array}{l}\text { excellent, } 1 \text { attempt to stand, } \\
\text { minimal or no ataxia }\end{array}$ \\
\hline
\end{tabular}


15 beats/min. Thus a bolus of $1 \mathrm{mg}$ atropine was given i.v. 5 minutes later its heart rate was regular with a frequency of 32 beats/min, sedation seemed to be adequate and anaesthesia was induced. The horse fell over backwards 45 seconds after the propofol and started paddling extensively and trying to lift its head. By sitting on its head it was maintained on the floor and the immediate administration of propofol to effect was started. During the next 2-3 minutes the horse was administered $66 \mathrm{ml}$ of propofol (1\%), the equivalent of its induction dose. As paddling became more severe, thiopentone was administered, until after a dose of $1 \mathrm{gr}$ the horse became calm. It was intubated, supplementation of oxygen ( $15 \mathrm{l} / \mathrm{min}$ ) started immediately and then it was connected to a hoist. After the thiopentone injection about 2-3 minutes had passed. Respiration seemed to be adequate, mucous membranes were pink and pulse regular and strong. The horse was lifted to transport it into surgery but within less than 30 seconds, it struggled so hard, that it had to be lowered again. It needed another $1.5 \mathrm{gr}$ of thiopentone to prevent it from moving. As the anaesthetist judged the horse to be uncontrollable it was transported back to the recovery box, where it lay calm on its side for 42 minutes. Then it got up excellently. The data from this horse are excluded from the other paragraphs.

\section{Cardiopulmonary effects}

\section{Arrhythmias}

Three horses showed II degree AV blocks just prior to anaesthesia induction. One horse was treated with atropine before anaesthesia induction (see above). In another horse heart rate before anaesthesia induction had fallen from 48 to 28 beats/ min and was not treated, but atropine was administered 15 min after anaesthesia induction as heart rate had dropped to 15. The horse was $370 \mathrm{~kg}$ and the initial dose of atropine was $1 \mathrm{mg}$ i.v. followed by another $2 \mathrm{mg}$ i.v. after 5 minutes as heart rate was still 15. Within another 2 minutes AV blocks disappeared, heart rate rose to $52 \mathrm{beats} / \mathrm{min}$ and remained there until the end of the surgery 65 minutes after anaesthesia induction. In the third horse, that showed II degree AV blocks just prior to anaesthesia induction these blocks disappeared spontaneously 40 minutes after anaesthesia induction.

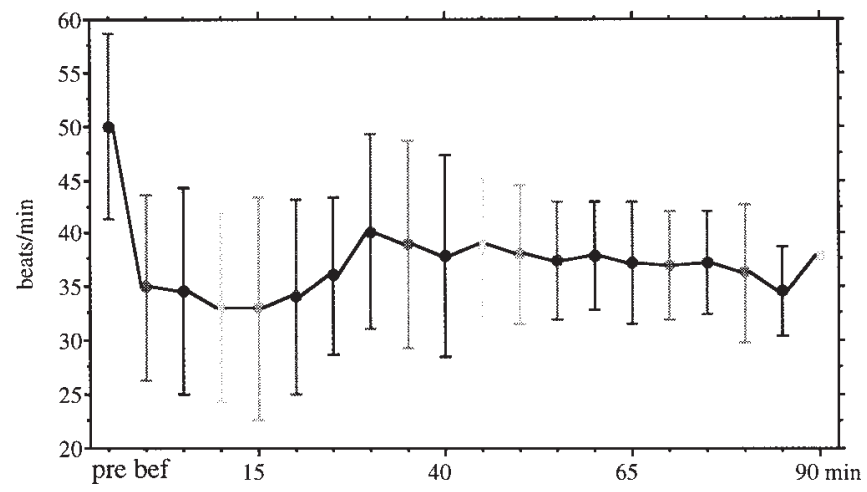

Fig. 1: Mean heart rates ( \pm SD) in 15 clinical cases anaesthetised with metetomidine-propofol, previously to any drug administration (pre), before anaesthesia induction (bef) and every five minutes during anaesthesia; time points at which heart rates of all animals $(n=15)$ are available.

Mittlere Herzfrequenz ( \pm SD) von 15 klinischen Patienten vor der Applikation jeglicher Medikamente (pre), vor der Anästhesieeinleitung (bef) und alle 5 Minuten unter Medetomidin-Propofol Anästhesie; Zeitpunkte zu welchen Herzfrequenzen aller Tiere gemessen wurden
2 horses showed sinus arrhythmias during the anaesthesia. In one horse, they started immediately after anaesthesia induction and ceased after 45 minutes; in the other horse they started 40 minutes after anaesthesia induction but remained throughout the whole anaesthesia.

\section{Heart rate}

Mean heart rates at time points at which data of all animals were available (clinical cases during 50 mins, in the field during 20 mins) are shown in figure 1 and 2 . In the clinical cases heart rate was significantly reduced compared to presedation values $(p<0.01$ up to 25 mins and $p<0.0530-50$ mins after anaesthesia induction). In the stallions, anaesthetised in the field, heart rates were significantly reduced $(p<0.01)$ compared to presedation values throughout the whole anaesthesia.

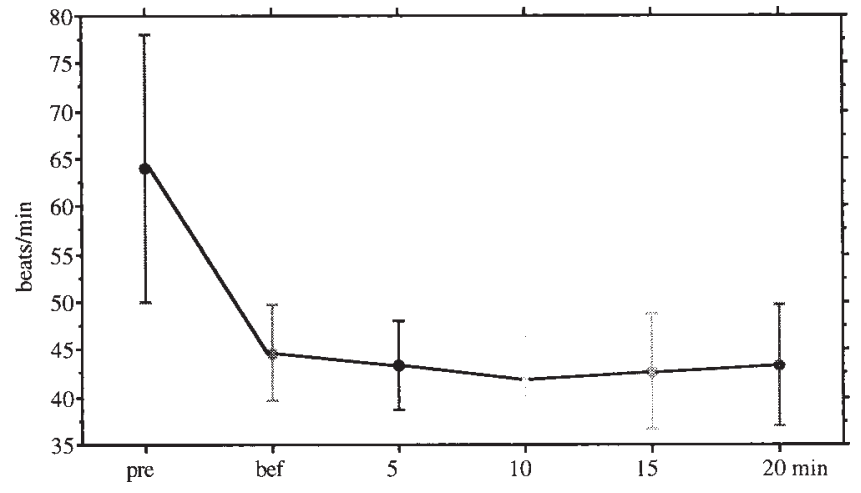

Fig. 2: Mean heart rates $( \pm$ SD) of 12 horses and ponies anaesthetised in the field; time points at which heart rates of all animals $(n=15)$ are available.

Mittlere Herzfrequenz ( \pm SD) von 12 Pferden und Ponies, anästhesiert unter Feldbedingungen, vor der Applikation jeglicher Medikamente (pre), vor der Anästhesieeinleitung (bef) und alle 5 Minuten unter Medetomidin-Propofol Anästhesie; Zeitpunkte zu welchen Herzfrequenzen aller Tiere gemessen wurden

\section{Arterial blood pressures}

The application of an intra-arterial catheter proved to be difficult in some horses. In 5 horses the anaesthetist was not able to sucessfully place an intra-arterial catheter.

Arterial blood pressures were very stable in individual animals over time and did not show variations greater than \pm 11 $\mathrm{mmHg}$. Occurring variations coincided with presence or absence of surgical stimuli. Mean arterial blood pressure (MAP) ranged from 95.6-111 with a range from 84-128.

In the one horse, in which heart rate 15 minutes after induction had dropped to 15 beats/min, for the first 20 minutes pulse was hardly palpable and mucous membranes looked very pale with no assessable capillary refill time (CRT). In this horse, for the first 25 minutes no intraarterial catheter could be placed and thus no pressure measurements were obtained. After 30 minutes (i.e. after the atropine) mucous membranes looked pink and CRT was 2 secs. MAP was $84 \mathrm{mmHg}$ and remained like this until the end of the anaesthesia. This horse underwent emergency surgery, because it had suffered from severe injuries on its legs including loss of an unknown amount of blood. PCV before anaesthesia induction had been $24 \%$ and plasma protein contents $68 \mathrm{~g} / \mathrm{L}$, otherwise clinical examination had revealed no other problems. 
Respiratory rate and arterial blood gases

Mean respiratory rates of clinical cases at time points at which data of all animals were available (during 45 minutes) are shown in figure 3. All animals showed a slowing of the respiratory rate after sedation with medetomidine. After anaesthesia induction four horses showed an increase of respiratory rate to presedation values ( \pm 2 breaths $/ \mathrm{min}$ ). In the first minute after becoming recumbent all horses showed pauses in respiration of 20-60 secs, but phases of apnoea no longer occurred.

During anaesthesia respiratory rate was stable in all animals. Careful observation detected that some changes of tidal volume or respiratory rate occurred with surgical stimulation or changes in anaesthetic depth.

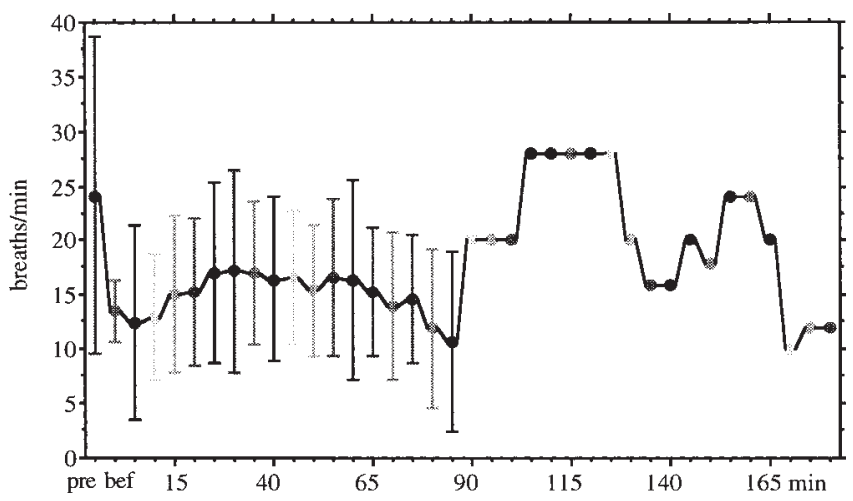

Fig. 3: Mean respiratory rates $( \pm S D)$ in 15 clinical cases anaesthetised with medetomidine-propofol, previously (pre) to any drug administration, before (bef) anaesthesia induction and every five minutes during anaesthesia. Time in mins after anaesthesia induction, $\mathrm{n}$ decreasing with time.

Mittlere Atemfrequenzen ( \pm SD) von 15 Patienten vor der Applikation jeglicher Medikamente (pre), vor der Anästhesieeinleitung (bef) und alle 5 Minuten unter Medetomidin-Propofol Anästhesie; $n$ mit der Zeit abnehmend

From anaesthesia induction onwards until the recovery phase, 4 animals, 3 of the horses in the field and one under clinical conditions showed irregular breathing patterns with respiratory breaks of up to 20 seconds, occurring every 1-3 minutes. Time course of mean arterial blood gas values are given in figure 4. and 5. Mean $\mathrm{p}_{\mathrm{a}} \mathrm{O}_{2}$ values ranged from to 23.2-31.8 $\mathrm{kPa}$ and mean $\mathrm{p}_{\mathrm{a}} \mathrm{CO}_{2}$ values ranged from 6.1 to $7.0 \mathrm{kPa}$. Lowest and highest registered $p_{a} \mathrm{O}_{2}$ values were 11.7 and 59.7 $\mathrm{kPa}$ respectively. Lowest and highest registered $\mathrm{p}_{\mathrm{a}} \mathrm{CO}_{2}$ values were 5.2 and $8.5 \mathrm{kPa}$ respectively.

Other than cardiopulmonary effects

All animals appeared very lightly anaesthetised, showing brisk palpebral reflexes and nystagmus of various degrees. Observers not involved in the experiments, were all amazed, that the animals did not move.

During anaesthesia a total of six animals (2 in the field and 4 in clinics) showed movements in response to surgical stimuli. Once this was only a shivering in the neck region, twice a slight nodding with the head and 3 times a movement with the foot. These movements were always slow in nature and easily controlled by bolus injections of $0.05-0.1 \mathrm{mg} / \mathrm{kg}$ propofol. In horses that had an intra-arterial catheter in place a rise in mean arterial blood pressure of 10-15 $\mathrm{mmHg}$ preceeded these movements.
Urination during or just after anaesthesia occurred in all animals. In clinical patients with estimated anaesthesia duration of $>60$ minutes, from the fourth clinical case onwards, urinary catheterisation was performed after anaesthesia induction.

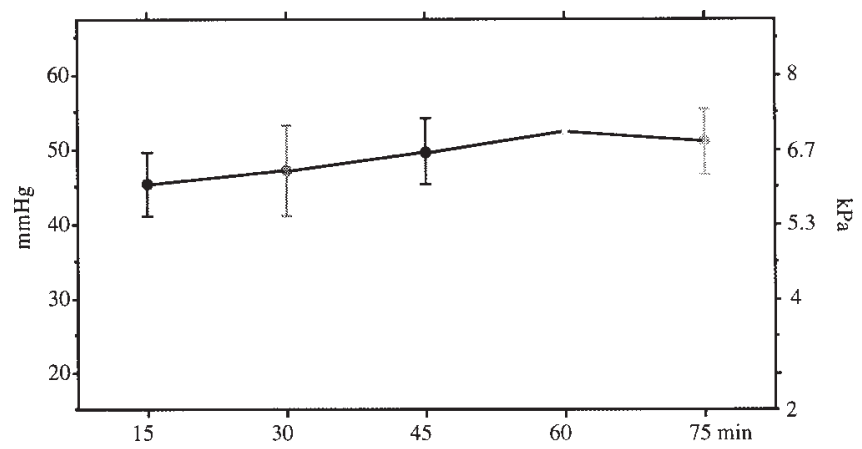

Fig. 4 : Mean $\mathrm{p}_{\mathrm{a}} \mathrm{CO}_{2}$ in 11 horses anaesthetised under clinical conditions using medetomidine-propofol.

Mittlere $\mathrm{p}_{\mathrm{a}} \mathrm{CO}_{2}-$ Werte von 11 Pferden welche unter klinischen Bedingungen mit Medetomidin-Propofol anästhesiert wurden.

Anaesthesia duration, propofol infusion rates and surgical conditions

In the clinical cases mean anaesthesia time was $79.0 \pm 36.04$ (50-175) mins and in the field $30.0 \pm 11.40$ (20-50) mins. During all surgeries, especially the castrations, surgeons were satisfied with the good relaxation of the animals. The obvious lack of violent "purposeful movements" and the ease of controllability is another noted advantage of this protocol.

Propofol infusion rates of the two groups are presented separately; as under field conditions the horses weights were only judged and they were also premedicated with acepromazine and not infused with medetomidine. Mean propofol infusion rates in the clinical patients are represented in figure 6 . They

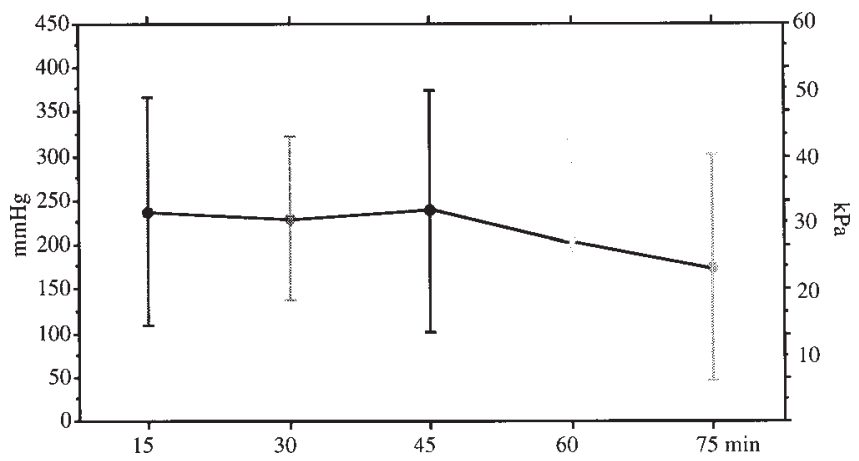

Fig. 5 : Mean $\mathrm{p}_{\mathrm{a}} \mathrm{O}_{2}$ in 11 horses anaesthetised under clinical conditions using medetomidine-propofol. Spontaneous ventilation, inspired $\mathrm{O}_{2}$ concentration $>90 \%$.

Mittlere $\mathrm{p}_{\mathrm{a}} \mathrm{CO}_{2}$-Werte von 11 Pferden welche unter klinischen Bedingungen mit Medetomidin-Propofol anästhesiert wurden.Atmung spontan inspiratorische $\mathrm{O}_{2}$ - Konzentration $>90 \%$

ranged from $0.085-0.105 \mathrm{mg} / \mathrm{kg} / \mathrm{min}$ with an individual range of $0.05-0.18 \mathrm{mg} / \mathrm{kg} / \mathrm{min}$. In all but three animals, the individual infusion rate could be maintained within \pm 0.015 $\mathrm{mg} / \mathrm{kg} / \mathrm{min}$ from the beginning of the anaesthesia onwards. In two animals, that suffered from fever (foal with polyartheritis) or had suffered from acute blood loss (injured horse, in which blood pressure and heart rate problems occurred initially) the initially chosen dose rate of $0.1 \mathrm{mg} / \mathrm{kg} / \mathrm{min}$ was reduced $\mathrm{im}$ mediately to $0.06 \mathrm{mg} / \mathrm{kg} / \mathrm{min}$, as their cardiovascular function 
and the reduction of reflexes suggested a too deep level of anaesthesia. One pony that was anaesthetised for castration and had been very difficult to handle before anaesthesia, had to be bolused with propofol several times within the first 10 minutes reaching an average dose rate of $0.18 \mathrm{mg} / \mathrm{kg} / \mathrm{min}$ of propofol. In this pony dose rate could be reduced with time reaching levels of $0.13 \mathrm{mg} / \mathrm{kg} / \mathrm{min} 50$ minutes after anaesthesia induction.

In the horses and ponies anaesthetised under field conditions mean propofol infusion rates reached from 0.063-0.18 mg/ $\mathrm{kg} / \mathrm{min}$, according to the judged weight.

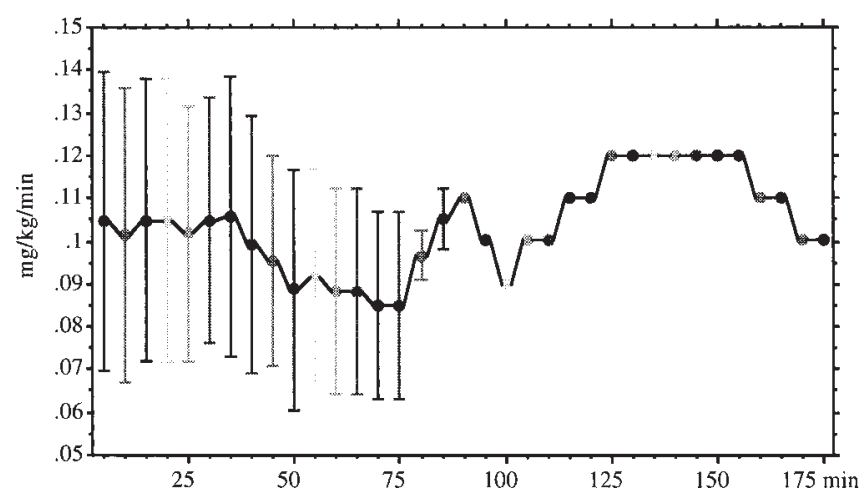

Fig. 6: Mean propofol infusion rates in $\mathrm{mg} / \mathrm{kg} / \mathrm{min}$ in 15 clinical patients anaesthetised with medetomidine-propofol TIVA. Time in mins after anaesthesia induction, $\mathrm{n}$ decreasing with time.

Mittlere Propofoldosierungen in $\mathrm{mg} / \mathrm{kg} / \mathrm{min}$ bei 15 klinischen Patienten welche mit Medetomidin-Propofol anästhesiert wurden. Zeit in Minuten nach Anästhesieeinleitung, $n$ mit der Zeit abnehmend

\section{Recovery}

Data concerning recovery are presented in table 3 . In the clinical cases recovery scores were the following: $2 \times 3,2 \times 4$ and $10 \times 5$ and in the field: $2 \times 3,6 \times 4$ and $4 \times 5$. The clinical cases took $10 \times 1,2 \times 2,1 \times 3$ and $1 \times 4$ attempts to stand and the horses in the field $10 \times 1$ and $2 \times 2$ attempts to stand.

Of the clinical cases, one pony was not allowed to recover as it suffered from inoperable lesions and had to be euthanized 60 minutes after anaesthesia induction.

A 6 week old foal, that was suffering from polyarthritis and had been anaesthetised 3 times (once with xylazine-ketamine followed by isoflurane and twice with xylazine-ketamine-climazolam, as described by Bettschart-Wolfensberger et al., 1996) within 10 days before the medetomidine-propofol anaesthesia. In this foal the recovery protocol was slightly changed. The state of health had not changed since its admission to the clinic and it had been pyrexic for 14 days. After the first three anaesthetics (duration 55-60 minutes) the foal had taken 62, 47 and 45 minutes to stand up, even though recovery had been assisted. Therefore it was not sedated for recovery after medetomidine propofol. 15 minutes after the end of infusion, at which stage it had not moved or shown any signs of recovery, it was given atipamezole by very slow i.v. injection $(60 \mu \mathrm{g} / \mathrm{kg}$ atipamezole diluted with saline to a volume of $20 \mathrm{ml}$ ). After a dose of $3 \mathrm{mg}$ of atipamezole $(=21 \mathrm{mg} / \mathrm{kg}$ atipamezole, that had taken about 2 minutes to inject) the foal started swallowing and moving its limbs. It was standing alertly within another 1.2 minutes and started sucking immediately.

The stallion that had shown poor anaesthesia induction quality in the field showed muscle tremor of the whole body and especially the limbs for 3 minutes during recovery.

\section{Discussion}

The aim of the present study was to test the practical use of a new TIVA regime for equidae (Bettschart-Wolfensberger et al., $2001 a+b)$. After a total of 27 anaesthesias the clinical testing of this regime was terminated, because of a relatively high incidence of unsatisfactory anaesthesia inductions, and one totally unacceptable induction phase in a horse, that almost resulted in injuries of people involved.

Medetomidine proved to be suitable as a preanaesthetic sedative in a practical situation. The previously tested dose of $7 \mu \mathrm{g} /$ $\mathrm{kg}$ was increased, based on subjective decision by an experienced anaesthetist. This would be routine practice with other alpha $_{2}$-adrenoceptor agonists under similar circumstances. None of the clinically anaesthetised horses needed further sedation but all the stallions castrated under field conditions did. These horses had not been handled at all, had been transported just before the anaesthetic and in six of them the application of an intravenous catheter had only been possible after the administration of some intramuscular acepromazine. Nevertheless the further administration of 2-6 $\mu \mathrm{g} / \mathrm{kg}$ medetomidine resulted in good sedation with total lack of response to under clinical circumstances normal external stimuli, such as people talking or approaching and other horses walking by. Because of this deep level of sedation, achieved in all horses, the author is convinced that none of the bad anaesthesia inductions or nonideal recoveries in this study can be attributed to lack of sedation.

The incidence of nonideal or bad anaesthesia induction phases in the present study, was relatively high compared to previous propofol reports. Nolan (1989) reported one fair anaesthesia induction phase out of four ponies that were sedated with detomidine and anaesthesia induced with propofol and Nolan and Hall (1985) reported some paddling after anaesthesia induction when the horses had been sedated with acepromazine and butorphanol but only smooth induction phases after sedation with xylazine. Taylor (1989a), Aguiar et al. (1993) or Pablo et al. (1997) all used detomidine or xylazine for premedication and propofol as an induction agent and only reported good anaesthesia inductions. None of the ponies or horses that weighed $<250 \mathrm{~kg}$ showed any problems during anaesthesia induction but the incidence of paddling after induction increased with increasing weight of the horse. In the larger horses the injection of the total dose of propofol took up to 55 secs. When these trials were performed, propofol was only available as a $1 \%$ solution resulting in very high injection volumes. Since the completion of this current work a $2 \%$ solution has become available. The onset of unconsciousness and anaesthesia is dependent on the time which the drug takes to achieve certain levels at its effect site, for propofol the brain, which again is mainly dependent on circulation to the brain and the drugs lipid solubility (Thurmon et al., 1996). From previous studies we know that a medetomidine bolus induces cardiovascular changes similar to other $\alpha_{2}$-adrenoceptor agonists in equidae (BettschartWolfensberger et al., 1999). The reduced cardiac index with medetomidine probably reduces the amount of propofol reaching the brain within a certain time and thus delays onset of unconsciousness. The number of horses in which propofol was used as an induction agent is low (Nolan and Hall, 1985; Nolan, 1989; Aguiar et al., 1993; Pablo et al., 1997) and thus only a blind comparison of different sedatives followed by propofol inductions would be able to really test if anaesthesia inductions are worse with medetomidine premedication than following other sedatives. 
One of the stallions anaesthetised in the field showed not only paddling of the limbs, but also spasms of the whole body immediately after anaesthesia induction as well as during recovery. In dogs different authors have reported spasms and stiffness after the use of propofol combined with different sedatives (Hall and Chambers, 1987; Watney and Pablo, 1992; Nolan et al., 1993; Kramer et al., 1995), the causes of which remained unknown. However Lagerweii et al. (1993) reported spontaneus limb movements during 2 hours of propofol infusion in dogs that did never occur if the same dogs were premedicated with medetomidine.

The horse that showed a very poor anaesthesia induction had been anaesthetised already in the same clinic 7 month before this episode. At that time anaesthesia had been induced with xylazine $(1.1 \mathrm{mg} / \mathrm{kg})$-ketamine $(2 \mathrm{mg} / \mathrm{kg})$-diazepam $(0.02 \mathrm{mg} /$ $\mathrm{kg}$ ) and maintained with halothane. On this first occasion also a bolus of $0.5 \mathrm{gr}$ thiopentone had been necessary to intubate and transport the horse into theatre, but otherwise anaesthesia had been uneventful. Why the use of medetomidine-propofol resulted in an absolutely unacceptable, and even with thiopentone, hardly controllable situation remains unknown. Horses dying of hypoxaemia can react violently and show extensive movement. We were not able to take an arterial blood sample in this horse, as it struggled so hard. Nevertheless we are convinced, that no severe hypoxaemia was present as mucous membranes were always pink, pulse rate regular and strong, the horse seemed to the anaesthetist to be conscious and the paddling ceased when thiopentone was administered. The influence of atropine administered just prior to induction in this horse is another unknown factor.

Already in previous medetomidine-propofol reports it was obvious that judgement of depth of this anaesthesia differs from that during inhalation anaesthesia. In the present study the author had already been familiar with the technique and did not have problems to control depth of anaesthesia. Clinical judgement of depth of anaesthesia is one of the major "holy grails" in anaesthesia. As long as a horse doesn't show purposeful movements during anaesthesia, the anaesthetist can not be certain, if depth of anaesthesia is adequate. The prompt recoveries noted in all animals suggest, that none of the horses were overdosed. In all animals propofol infusion was started at an infusion rate of $0.1 \mathrm{mg} / \mathrm{kg} / \mathrm{min}$. Only in a foal and one horse, both in poor condition, was the dose rate reduced to $0.06 \mathrm{mg} / \mathrm{kg} / \mathrm{min}$ rapidly after anaesthesia induction. If the patient did not show any reaction on surgical stimulus the infusion rate was decreased by $0.01 \mathrm{mg} / \mathrm{kg} / \mathrm{min}$ every $15-20$ minutes. Mean infusion rates of propofol of $0.85-0.105 \mathrm{mg} / \mathrm{kg} / \mathrm{min}$ that were necessary to maintain anaesthesia were within the ranges determined in previous studies (Bettschart-Wolfensberger et al., $2001 a+b)$. These infusion rates were much lower than those used by other authors that combined propofol with various sedatives, analgesics or muscle relaxants (Nolan and Hall, 1985; Taylor, 1989a; Matthews et al., 1994; Taylor et al., 1997; Mama et al., 1998). Only combination of propofol with constant ketamine infusion resulted in propofol infusion rates comparable with the one described here (Flaherty et al., 1997). In this current study we maintained anaesthesia as light as possible, to reduce cardiopulmonary side effects, thus making a fatal outcome less likely. This resulted in purposeful movements in 6 horses. Contrary to TIVA based on ketamine (Wolfensberger, 1992), these movements were always gentle and easy to controll by slow injection of a propofol bolus of $0.05-0.1 \mathrm{mg} / \mathrm{kg}$. Although anaesthesia was maintained at such a light level the surgeons always considered muscle relaxation good and as the occurring movements were always gentle everybody in theatre gained quickly confidence to the new anaesthetic.

Hypoxaemia has been the biggest problem with medetomidine-propofol TIVA in the previous studies (Bettschart-Wolfensberger et al., 200 $1 a+b$ ). Thus clinical patients were allowed to breath $>90 \%$ oxygen from the start of anaesthesia. Mean $\mathrm{p}_{\mathrm{a}} \mathrm{O}_{2}$ values, although lower than theoretically possible with pure oxygen ventilation, were within ranges that are common in clinically anaesthetised horses breathing spontaneously pure oxygen. It has been recognised a long time ago, that in recumbent horses often huge alveolar-arterial oxygen differences occur (Hall et al., 1968), mainly attributable to ventilation-perfusion disturbances. The minimal $\mathrm{p}_{\mathrm{a}} \mathrm{O}_{2}$ value of $11.7 \mathrm{kPa}$ registered in a horse on its back 60 minutes after anaesthesia induction cannot be interpreted as an unacceptable respiratory depression due to medetomidine-propofol. In a clinical survey in horses that were anaesthetised with halothane in oxygen and breathing spontaneously, $5 \%$ of the horses on their back developed hypoxaemia (defined as $\mathrm{p}_{\mathrm{a}} \mathrm{O}_{2}<60 \mathrm{mmHg}=8 \mathrm{kPa}$ ) from the beginning of anaesthesia and $35 \%$ by its end, 101 minutes after anaesthesia induction (Day et al., 1995). We still do lack an explanation for the relatively large number of severe hypoxaemias, that occurred in the previous studies with medetomidinepropofol (Bettschart-Wolfensberger et al., 2001a+b). The present results suggest, that medetomidine-propofol, administered at adequate dose rates does not induce greater hypoxaemia than do other general anaesthetics in horses.

$\mathrm{P}_{\mathrm{a}} \mathrm{CO}_{2}$ values were within normal limits for horses under general anaesthesia with a relatively low maximal value of $8.5 \mathrm{kPa}$ registered in a horse in lateral recumbency, 75 minutes after anaesthesia induction.

Bradyarrhythmias after the use of medetomidine are common in dogs (Vainio et al., 1986/87; Lombard et al., 1989; Nilsfors et al., 1989; Kramer et al., 1996). Their effects, other than a reduction in cardiac output and the potential danger during a

Tab. 3: Recovery times (in minutes from end of infusion) and scores in 14 equidae anaesthetised under clinical conditions (Clin) or in the field (Field) following medetomidine-propofol infusion anaesthesia.

Aufwachzeiten (Zeit in Minuten nach Beendigung der Infusion) und Qualität der Aufwachphase von 14 Equiden unter klinischen Bedingungen (Clin) oder unter Feldbedingungen (Field)

\begin{tabular}{|l|l|l|}
\hline & $($ Clin, $\mathrm{n}=14))$ & (Field, $\mathrm{n}=12)$ \\
\hline time of extubation (mins) & $\begin{array}{l}9.9 \pm 6.92 \\
(2.1-25.2)\end{array}$ & - \\
\hline 1. movement (mins) & $\begin{array}{l}13.5 \pm 7.39 \\
(2.1-25.2)\end{array}$ & $\begin{array}{l}12.6 \pm 6.66 \\
(6.1-24.6)\end{array}$ \\
\hline into sternal recumbency (mins) & $\begin{array}{l}18.2 \pm 9.24 \\
(3.2-36.0)\end{array}$ & $\begin{array}{l}181+1 \cap 0.3 \\
(8.7-31.8)\end{array}$ \\
\hline $\begin{array}{l}\text { duration of sternal recumbency } \\
\text { (mins) }\end{array}$ & $\begin{array}{l}8.5 \pm 8.06 \\
(0.52-26.2)\end{array}$ & $\begin{array}{l}2.0 \pm 1.66 \\
(0-4.45)\end{array}$ \\
\hline standing (mins) & $\begin{array}{l}27.1 \pm 9.96 \\
(12.2-44.8)\end{array}$ & $\begin{array}{l}20.7 \pm 11.19 \\
(10.0-35.1)\end{array}$ \\
\hline \hline nr. of attempts to stand & $\begin{array}{l}1.5 \pm 0.94 \\
(1-4)\end{array}$ & $\begin{array}{l}1.2 \pm 0.39 \\
(1-2)\end{array}$ \\
\hline $\begin{array}{l}\text { recovery score (1-5; } 1 \text { = worst, } \\
5=\text { best) }\end{array}$ & $\begin{array}{l}4.6 \pm 0.76 \\
(3-5)\end{array}$ & $\begin{array}{l}4.2 \pm 0.75 \\
(3-5)\end{array}$ \\
\hline
\end{tabular}


general anaesthetic, are a matter of discussion. Anticholinergics can prevent these bradyarrhythmias, but their use has been questioned, as it may result in very high blood pressures (Bergström, 1988; Alibhai et al., 1996). In horses a reduction of heart rate after the use of any $\alpha_{2}$-adrenoceptor agonist is common (England and Clarke, 1996). Pretreatment with anticholinergics is not recommended as anticholinergics also induce disturbances of vision and depression of gastrointestinal motility (Hall and Clarke, 1983). Nevertheless in two horses in which heart rates had dropped to 15 beats/min atropine was administered to maintain cardiac output. Compared to atropine doses of $0.005-0.01 \mathrm{mg} / \mathrm{kg}$ used by other authors (Short et al., 1986; Gasthuys et al., 1990) the doses of 0.003 and $0.008 \mathrm{mg} / \mathrm{kg}$ we used were rather low but resulted in heart rates within normal ranges within 5 minutes.

In dogs heart rate tends to rise during propofol infusion following medetomidine premedication (Lagerweij et al., 1993; Hammond and England, 1994; Hall et al., 1997). A rise in heart rate occurred in the clinical cases in this study but not in the horses in the field, probably because the observation period had been too short.

Two horses showed sinus arrhythmias during the propofol infusion, a fact that had not been observed during the anaesthesias of the ponies in the previous medetomidine-propofol studies (Bettschart-Wolfensberger et al., 2001a+b), significance of which is unknown.

After anaesthesia induction the placement of an arterial catheter was not always easy probably due to peripheral vasoconstriction induced by medetomidine (Docherty and Mc-Grath, 1980). Such problems, but with the catheterisation of veins have been reported in cats after the premedication with medetomidine (Becker and Oechtering, 1996). Peripheral vasoconstriction was also noted by other authors. Lagerweij et al. (1993) reported frequently cadaveric appearence of the oral mucous membranes and paleness of the conjunctival membranes after medetomidine premedication and explained this with hypoperfusion of some vascular beds due to increased vascular resistance from selective vasoconstriction. We noted alarmingly pale mucous membranes in one horse only, the one in which heart rate fell to 15 beats/min. Circulation was failing probably due to the reduction of heart rate caused by medetomidine but also due to a fall in blood pressure caused by propofol. In this horse the amount of blood loss and the general status before the anaesthesia had probably been underestimated. In the horses in which arterial blood pressure was measured, it was very stable and within ranges commonly accepted as being adequate during horse general anaesthesia. The clinical significance of an adequate blood pressure should not be overinterpreted during medetomidine-propofol anaesthesia. Data from previous studies in ponies (Bettschart-Wolfensberger et al., 2001a+b) and from dog studies suggest that arterial blood pressure is mainly dependent on the proportion of propofol plasma concentration to medetomidine plasma concentration (Vainio, 1991; Lagerweij et al., 1993; Hall et al., 1997). Thus a horse can show a "good" blood pressure even with a low cardiac output, if peripheral vasoconstriction is present.

Urine production was not assessed objectively in the present study. Nevertheless horses were noted to urinate unusually large quantities either during anaesthesia or recovery, or immediately after recovery. The problem of very large urine production due to the use of medetomidine had been noted previously (Bettschart-Wolfensberger et al., $2001 a+b$ ). Neverthe- less it was surprising that stallions undergoing castrations of only 20 minutes duration urinated during anaesthesia or right after recovery. Urinating during anaesthesia can contaminate the surgical site and an extended bladder may cause discomfort during recovery. The increased fluid loss during longer surgeries should be taken into account and replaced with i.v. fluid. In clinical patients we started, after the fourth case, to regularly induce an urinary catheter at the beginning of surgery to reduce problems. However this enormous urine production is certainly a relatively big disadvantage of the present TIVA regime. In the present study the protocol was such that none of the clinical patients received preemptive analgesia. To administer an analgesic before surgery is considered the best option to prevent "wind up" phenomenon (Woolf, 1983). Medetomidine itself has marked analgesic properties and we wished to get an idea if the analgesia persists any longer than the sedative action. Thus we chose not to pretreat the horses with analgesics. We did not perform any sophisticated testing of analgesia or present pain after surgery, but only watched the horses right after recovery in their box as well as one and 4 hours later. All the horses started eating as soon as they were returned to their box and remained totally calm as long as they were observed. We were amazed by this fact as, at least in the four intraabdominal surgeries we were expecting some reactions. In such surgeries the routine preoperative application of flunixin meglumine is very often insufficient, many horses show some signs of colic after surgery and have to be treated with supplemental analgesia. This postoperative analgesic action of medetomidine could be a big advantage of the use of this drug in the perioperative period.

In previous studies (Bettschart-Wolfensberger et al., 2001a+b) the use of atipamezole after medetomidine propofol anaesthesia has been tested. It was concluded, that atipamezole should not be routinely used as recovery was not improved and, as its use could result in antagonism of not only the sedative but also the analgesic component of medetomidine. In foals it is very important, that they wake up as soon as possible from general anaesthesia to start sucking. During recovery an infusion therapy is not possible and the foals can become hypoglycaemic and their energy metabolism can disregulate. This can be very harmful especially in foals that suffer from other diseases. Matthews et al. (1994) have reported the successful use of propofol in foals with very quick recoveries. Thus we decided to use medetomidine-propofol followed by atipamezole in recovery in a foal that underwent its fourth anaesthetic and was severly ill. As antibiotics, low plasma proteins, poor state of health and neonatal age certainly influence pharmacokinetics of a drug, we had no idea of the necessary dose rate of atipamezole. We have shown that the onset of its action is very quick (Bettschart-Wolfensberger et al., 1999). Thus we gave it by very slow injection and stopped as soon as we noted signs of awakening. It was impressive how within not even two minutes the foal was standing, totally alert and sucking.

In horses recovery quality is one of the most important features of an anaesthetic regime, as fatalities often happen during this period (Young and Taylor, 1993). In experimental animals, testing of recovery quality is very difficult, as it usually improves with repeated anaesthetics. The horses are not in an unfamiliar environment any more and most often no pain is present. Multiple observations on experimental animals will give results different from those of single observations on a large number of animals. As reported by other authors that used propofol in horses, overall recovery quality was good and of acceptable length. We 
failed to test if fatalities during recovery could be reduced by the routine use of medetomidine-propofol TIVA, as a much larger number of clinical cases would be necessary to do so. In the present study we have shown that an infusion of medetomidine-propofol results in good quality and easy controllable anaesthesia. Cardiovascular changes were within expected ranges and hypoxaemia was no more severe than during routine general horse anaesthesia. However problems with anaesthesia induction limited the use of propofol and implicated the termination of the trial. Further investigations of alternative induction agents are necessary. The availability of a medetomidine antagonist proved to be very useful to speed recovery in one foal which was severely ill.

\section{Literature}

Aguiar A., C.A. Hussni, St.P. Luna, G.B. Castro, F. Massone and A.L.G. Alves (1993): Propofol compared with propofol/guaifenesin after detomidine premedication for equine surgery. J. vet. Anaesth., 20, 26-28

Alibhai H.I.K., K.W. Clarke, Y.H. Lee and J. Thompson (1996): Cardiopulmonary effects of combinations of medetomidine hydrochloride and atropine sulphate in dogs. Vet Rec, 138, 11-13.

Becker C. and G. Oechtering (1996): Die Anästhesie mit Medetomidin und Ketamin bei der Katze. Kleintierpraxis, 41, 235-312.

Bergström K. (1988): Cardiovascular and pulmonary effects of a new sedative/analgesic (medetomidine) as a preanaesthetic drug in the dog. Acta vet Scand, 29, 109-116.
Bettschart-Wolfensberger R., P.M. Taylor, J.W. Sear, M.R. Bloomfield, K. Rentsch and S. Dawling (1996): Physiologic effects of anesthesia induced and maintained by intravenous administration of a climazolam-ketamine combination in ponies premedicated with acepromazine and xylazine. Am J Vet Res, 57, 1472-1477.

Bettschart-Wolfensberger R., R.W. Bettschart, O. Vainio, D. Marlin and K.W. Clarke (1999): Cardiopulmonary effects of a two hour infusion of medetomidine and its reversal by atipamezole in horses and ponies. J Vet Anaesth.26, 8-12.

Bettschart-Wolfensberger R., S. Freemann, N. Jäggin-Schmucker and K.W. Clarke (2001a): Infusion of a combination of propofol and medetomidine for long-term anesthesia in ponies, Am J Vet Res 62, 500-507.

Bettschart-Wolfensberger R., I.M. Bowen, S. Freemann, R. Feller, R.W. Bettschart, A. Nolan and K.W. Clarke K.W. (2001 b): Cardiopulmonary effects of prolonged anesthesia via propofol-medetomidine infusion in ponies, Am J Vet Res, In Press

Chang T. and A.J. Glazko (1974): Biotransformation and disposition of ketamine. International Anesthesiology Clinics, 12, 157-177.

England G.C.W., K.W. Clarke and L. Goossens (1992): A comparison of the sedative effects of three $\alpha_{2}$-adrenoceptor agonists (romifi-dine, detomidine and xylazine) in the horse. J. vet. Pharmacol. Therap., 15, 194-201.

England G.C.W. and K.W. Clarke (1996): $\mathrm{Alpha}_{2}$ adrenoceptor agonists in the horse - a review. Br. vet. J., 152, 641-657.

Flaherty D., J. Reid, E. Welsh, A.M. Monteiro, P. Lerche and A. Nolan (1997): A pharmacodynamic study of propofol or propofol and ketamine in ponies undergoing surgery. Res Vet Sci, 62, 179-184.

Gasthuys F., D. Parmentier, L. Gossens and A. De Moor (1990): A preliminary study on the effects of atropine sulphate on bradycardia and heart blocks during romifidine sedation. Vet Res Comm, 14, 489-502. 
Greene S.A., J.C. Thurmon, W.J. Tranquilli and G.J.Benson (1986): Cardiopulmonary effects of continuous intravenous infusion of guaifenesin, ketamine, and xylazine in ponies. Am J Vet Res, 47, 2364-2367.

Hall L.W., J.R. Gillespie and W.S. Tyler (1968): Alveolar-arterial oxygen tension differences in anaesthetized horses. Brit. J. Anaesth., 40, 560568.

Hall L.W. and K.W. Clarke (1983): Anaesthesia of the horse. In K.W.Clarke. L.W. Hall (Eds.), Veterinary anaesthesia. London: Baillière-Tindall, 203-244

Hall L.W. and J.P. Chambers (1987): A clinical trial of propofol infusion anaesthesia in dogs. J Small Anim Pract, 28, 623-637.

Hall L.W., E. Lagenweii, A.M. Nolan and J.W. Sear (1997): Disposition of propofol after medetomidine premedication in beagle dogs. J. vet. Anaesth., 24, 23-29.

Hammond R.A. and G.C.W. England (1994): The effect of medetomidine premedication upon propofol induction and infusion anaesthesia in the dog. J. vet. Anaesth., 21, 24-28.

Hartsfield S.M., N.S. Matthews, T.S. Taylor, R.N. Hooper and S.W. Erickson (1994): Detomidine-propofol anesthesia for carotid artery translocation in donkeys. Vet Surg, 23, 75-76.

Johnston G.M. (1995): The risks of the game: the confidental enquiry into perioperative equine fatalities. Br. vet. J., 151, 347-349.

Johnston G.M., P.M. Taylor, M.A. Holmes and J.L.N. Wood (1995): Confidental enquiry into perioperative equine fatalities (CEPEF-1): preliminary results. Equine vet. J., 27, 193-200.

Kramer S., A. Engelke und I. Nolte (1995): Motorische Krampfanfälle unter Propofol-Anästhesie beim Hund. Kleintierpraxis, 40, 63-65.

Kramer S., I. Nolte and W. Jöchle (1996): Clinical comparison of medetomidine with xylazine/l-methadon in dogs. Vet Rec, 138, 128133.

Lagerweij E., L. Hall and A.M. Nolan (1993): Effects of medetomidine premedication on propofol infusion anaesthesia in dogs. J. vet. Anaesth., 20, 78-83.

Lombard C.W., C. Kvart, H. Säteri, G. Holm and L. Nilsfors (1989): Effects of medetomidine in dogs with mitral regurgitation. Acta vet Scand, 85, 164-174.

Luna S.P.L., P.M. Taylor and M.KJ. Wheeler (1996): Cardiorespiratory, endocrine and metabolic changes in ponies undergoing intravenous or inhalation anaesthesia. J. vet. Pharmacol. Therap., 19, 251-258.

Mama K.R., P.J. Pascoe, E.P. Steffey and C. Kollias-Baker (1998): Comparison of two techniques for total intravenous anesthesia in horses. Am J Vet Res, 59, 1292-1298.

Matthews N.S., N.K. Chaffin, S.M. Hartsfield and W.A. Overhulse (1994): Propofol for immobilization of neonatal foals. Vet Surg, 23, 76.

Nilsfors L., L. Garmer and A. Adolfsson (1989): Sedative and analgesic effects of medetomidine in dogs - open clinical study. Acta vet Scand, 85, 155-159.

Nolan A.M. and L.W. Hall (1985): Total intravenous anesthesia in the horse with propofol. Equine vet. J., 17, 394-398.

Nolan A.M. (1989): The use of propofol as an induction agent after detomidine premedication in ponies. J Assoc Vet Anaesth, 16, 3032.

Nolan A.M., J. Reid and S. Grant (1993): The effects of halothane and nitrous oxide on the pharmacokinetics of propofol in dogs. J. vet. Pharmacol. Therap., 16, 335-342.

Nolan A.M., J. Reid, E. Welsh, D. Flaherty, R. McCormack and A.M. Monteiro (1996): Simultaneous infusions of propofol and ketamine in ponies premedicated with detomidine: a pharmacokinetic study. Res Vet Sci, 60, 262-266.

Pablo J., J. Bailey and C. Nicklin (1997): Evaluation of guaifenesinpropofol and sevoflurane in premedicated horses. Proc. 6th Int. Conf. of Vet. Anaest., 123.

Short C.E., N. Matthews, R. Harvey and C.L. Tyner (1986): Cardiovascular and pulmonary function studies of a new sedative/analgetic (detomidine/domosedan ${ }^{\circledR}$ ) for use alone in horses or as a preanesthetic. Acta vet. scand., 82, 139-155.

Taylor P.M. (1989): Adrenocortical response to propofol infusion in ponies: a preliminary report. J Assoc Vet Anaesth, 16, 12-14.

Taylor P.M. and S.P.L. Luna (1995): Total intravenous anaesthesia in ponies using detomidine, ketamine and guaifenesin: pharmacokinetics, cardiopulmonary and endocrine effects. Res Vet Sci, 59, 17 23.

Taylor P.M., A.L. Fowden and M.R. Bloomfield (1997): Propofol anaesthesia for surgery in late gestation pony mares. Proc. 6th Int. Conf. of Vet. Anaest., 122.

Tendillo F.J., A. Mascias, M. Santos, I.A.G. Segura, F.S. Roman and J.L. Castillo-Olivares (1996): Cardiopulmonary and analgesic effects of xylazine, detomidine, medetomidine and the antagonist atipamezole in isoflurane-anesthetized swine. Lab Anim Sci, 46, 215 219.

Thurmon J.C., W.J. Tranquilli and G.J. Benson (1996): Considerations for general anesthesia. In W. J. T. a. G. J. B. J. C. Thurmon (Eds.), Lumb and Jones Veterinary Anesthesia, 3rd edition5-34. Baltimore: Williams and Wilkins, 203-244

Tranquilli W.J., J.C. Thurmon, G.J. Benson and G.J. Davies (1986): Alteration in the arrhythmogenic dose of epinephrine (ADE) following xylazine administration to halothane-anesthetized dogs. J Vet Pharm Ther, 9, 198-203.

Vainio O., L. Palmu, R. Virtanen and J. Wecksell (1986/87): Medetomidine, a new sedative and analgesic drug for dogs and cats. J. vet. Anaesth., 14, 53-55.

Vainio O. (1991): Propofol infusion anaesthesia in dogs pre-medicated with medetomidine. J. vet. Anaesth., 18, 35-37.

Watney, G.C.G. and L.S. Pablo (1992): Median effective dosage of propofol for induction of anesthesia in dogs. Am J Vet Res, 53, 2320 2322.

Whitehair K.J., E.P. Steffey, N.H. Willits and M.J. Woliner (1993): Recovery of horses from inhalation anesthesia. Am J Vet Res, 54, 1693 1702.

Woolf C.J. (1983): Evidence for a central component of post injury pain hypersensitivity. Nature, 306, 686-688.

Wolfensberger R. (1992): Reversible Injektionsnarkose beim Pferd eine neve Narkose für den praktischen Tierarzt. In Bundesverband Praktischer Tierärzte e. V. Nürnberg/Deutschland.

Wolfensberger R. (1993): Ketamine-climazolam anaesthesia in horses. J. vet. Anaesth., 20, 49.

Yliselä E. and O. Vainio (1989): Effects of medetomidine on the experimental auricular pain in dogs. Acta vet Scand, 85, 187-191.

Young L.E., D.H. Bartram, M.J. Diamond, A.S. Gregg and R.S. Jones (1993): Clinical evaluation of an infusion of xylazine, guaifenesin and ketamine for maintenance of anaesthesia in horses. Equine vet. J., 25, 115-119.

Young S.S. and P.M. Taylor (1993): Factors influencing the outcome of equine anaesthesia: A review of 1314 cases. Equine vet. J., 25, $147-$ 151.

Regula Bettschart-Wolfensberger, Dr. med vet, PhD, Dipl ECVA

Oberassistentin Anästhesie

Veterinär-Chirurgische Klinik der Universität Zürich

Winterthurerstr. 260

CH 8057 Zürich

Tel: 004116358477

Fax: 004116358905

e-mail: bettwolf@vetchir.unizh.ch 